\title{
LITERATURE REVIEW : PENERAPAN MANAJEMEN RISIKO DI UNIT FILING
}

\author{
Vivi Anika Retno Mumpuni ${ }^{1}$, Sri Sugiarsi², Tunjung Bayu Sinta ${ }^{3}$
}

vivianika016@gmail.com, sri.sugiasri7@gmail.com, tunjungbayusintaa@gmail.com

\begin{abstract}
Risk is the possibility of unwanted or unexpected adverse effects in an activity. These risks can have a negative impact on officers who are present during activities, especially in theunit filing. There are several risks of work accidents experienced byworkers, filing such as fingers with staples attached to medical record documents, workers filing can get cough if they take or return medical record documents without wearing a mask. The purpose of the study was to determine the application of risk management in theunit filing. The research method used is Literature Review with a search strategy usingresults criteria Google Scholarwith the keywords "Risk management OR Implementation of Risk Management in theunit filing". The results of this study indicate that risk management in hospitals is carried out internally, therisk factor in theunit filing most prominentis that the officer can catch a cough if he does not use a mask, and the hand can cut the cover of the medical record document if he does not use gloves, attitude towards risk What happens in the filing unit is the creation of a work safety SOP to prevent unwanted risks. Factors that cause risk are chemical factors, biological factors, physical factors and ergonomic factors.
\end{abstract}

Keywords : Risk Management, Application of Risk Management

\begin{abstract}
Abstrak
Risiko merupakan kemungkinan terjadinya akibat buruk yang tidak di inginkan atau tidak terduga dalam sebuah aktivitas. Risiko tersebut dapat menghasilkan dampak negatif bagi petugas yang ada saat aktivitas terutama di unit filing. Terdapat beberapa risiko kecelakaan kerja yang di alami oleh petugas kerja filing seperti jari yang terkena steples yang menempel pada dokumen rekam medis, petugas kerja filing dapat terkena penyakit batuk jika mengambil atau menggembalikan dokumen rekam medis tanpa menggunakan masker. Tujuan penelitian untuk mengetahui penerapan manajemen risiko di unit filing. Metode penelitian yang digunakan adalah Literature Review dengan strategi pencarian menggunakan kriteria hasil Google Scholar dengan kata kunci "Manajemen risiko OR Penerapan Manajemen Risiko di unit filing”. Hasil penelitian ini bahwa pengelolaan manajemen risiko di rumah sakit di lakukan secara internal, faktor risiko di unit filing yang paling menonjol adalah petugas dapat terserang batuk apabila tidak menggunakan masker, dan tangan dapat tersayat sampul dokumen rekam medis apabila tidak menggunakan sarung tangan, sikap atas risiko yang terjadi di unit filing adalah dengan di buatkanya SOP keselamatan kerja untuk mencegah terjadinya risiko yang tidak di inginkan. Faktor yang menyebabkan terjadinya risiko yaitu faktor kimia, faktor biologi, faktor fisik dan faktor ergonomi.
\end{abstract}

Kata Kunci : Manajemen Risiko, Penerapan Manajemen Risiko

\section{PENDAHULUAN}

Manajemen Risiko adalah proses yang proaktif dan kontinu meliputi identifikasi, analisis, evaluasi, pengendalian, informasi komunikasi, pemantauan, dan pelaporan risiko, termasuk berbagai strategi yang dijalankan untuk mengelola Risiko dan potensinya. Manajemen Risiko Terintegrasi adalah proses identifikasi, analisis, evaluasi dan pengelolaan semua risiko yang potensial dan diterapkan terhadap semua unit/bagian/program/kegiatan mulai dari penyusunan rencana strategis, penyusunan dan pelaksanaan program dan anggaran, pertanggungjawaban dan monitoring dan evaluasi serta pelaporan. (PERMENKES No 25 Tahun 2019)

Penerapan manajemen risiko di unit filing adalah upaya menganalisis sistem yang ada terhadap potensi kesalahan untuk mencegah terjadinya insiden di bagian filing. Manajemen risiko merupakan suatu usaha terorganisir untuk mengidentifikasi, menyusun prioritas risiko, menganalisis dan mengurangi potensi risiko yang mungkin terjadi di bagian filing, pada pasien, pengunjung, staff dan aset organisasi, Manajemen risiko merupakan suatu usaha untuk mengetahui, menganalisa serta mengendalikan risiko dalam setiap kegiatan rumah sakit dengan tujuan untuk memeperoleh efektifitas dan efisiensi yang lebih tinggi. Meningakatkan mutu pelayanan kesehatan yang baik maka rumah sakit membutuhkan manajemen risiko. (Darmawi, 2016). Penerapan Manajemen Risiko Kesehatan ditempat kerja mempunyai tujuan meminimalisir kerugian akibat kecelakaan dan sakit, meningkatkan kesempatan peluang untuk meningkatkan produksi melalui suasana kerja yang aman, sehat dan nyaman, memotong mata rantai kejadian kerugian akibat kegagalan. (Mulyawan, 2015)

Menurut Feggy Aldila (2019) Menjelaskan bahwa di ruang penyimpanan rekam medis belum di lakukan adanya identifikasi risiko, tetapi untuk mencegah risiko yang terjadi yaitu tangan terluka, kepala rekam 
medis beserta koordinator rekam medis melakukan pemantauan terhadap perkembangan jumlah pasien. Menurut Intan Sari (2020) Mengatakan bahwa pelaksanaan manajemen risiko di unit filing dilakukan oleh semua petugas, untuk mencegah semakin banyaknya kerugian yang diakibatkan karena risiko, maka perlu dilakukanya pengendalian agar tidak terjadinya risiko yang tidak di inginkan.

Masih terdapat masalah dalam penerapan manajemen risiko bahwa manajemen risiko belum di terapkan dan belum adanya SOP dalam keselamatanm bekerja, risiko yang mungkin terjadi di unit filing karena petugas filing tidak menerapkan aturan aturan yang harus dilaksanakan agar menggurangi terjadinya risiko seperti petugas dapat terkena batuk jika mengambil atau menggembalikan dokumen rekam medis tanpa memakai masker, petugas filing dapat tersayat sampul dokumen rekam medis tanpa memakai sarung tangan. Berdasarkan latar belakang tersebut, peneliti tertarik untuk melakukan kajian Literature Review tentang "Penerapan Manajemen
Risiko di Unit Filing" untuk mengetahui Penerapan Manajemen Risiko kerja petugas filing dan untuk meminimalisir terjadinya risiko kerja petugas filing rumah sakit.

\section{METODE}

Penelitian ini menggunakan desain Literature review penelitian yang mengkaji artikel penelitian terkait penerapan manajemen risiko di unit filing, untuk selanjutnya ditarik kesimpulan. Pencarian data tersebut menggunakan database Google Scholar. Kata kunci yang digunakan yaitu "Manajemen Risiko OR Penerapan Manajemen Risiko Di Unit Filing", dan menggunakan bollean "OR". Dari hasil pencarian ditemukan sebanyak 15 artikel kemudian dipilih sebanyak 5 yang memenuhi kriteria inklusi yaitu diterbitkan dalam rentang tahun 2016-2020, rancangan penelitian menggunakan kualitatif, bahasa yang digunakan adalah Bahasa Indonesia.

\section{HASIL DAN PEMBAHASAN}

\section{A. Hasil}

1. Hasil Ekstraksi Data

Tabel 3.1

Hasil Ekstrasi Data

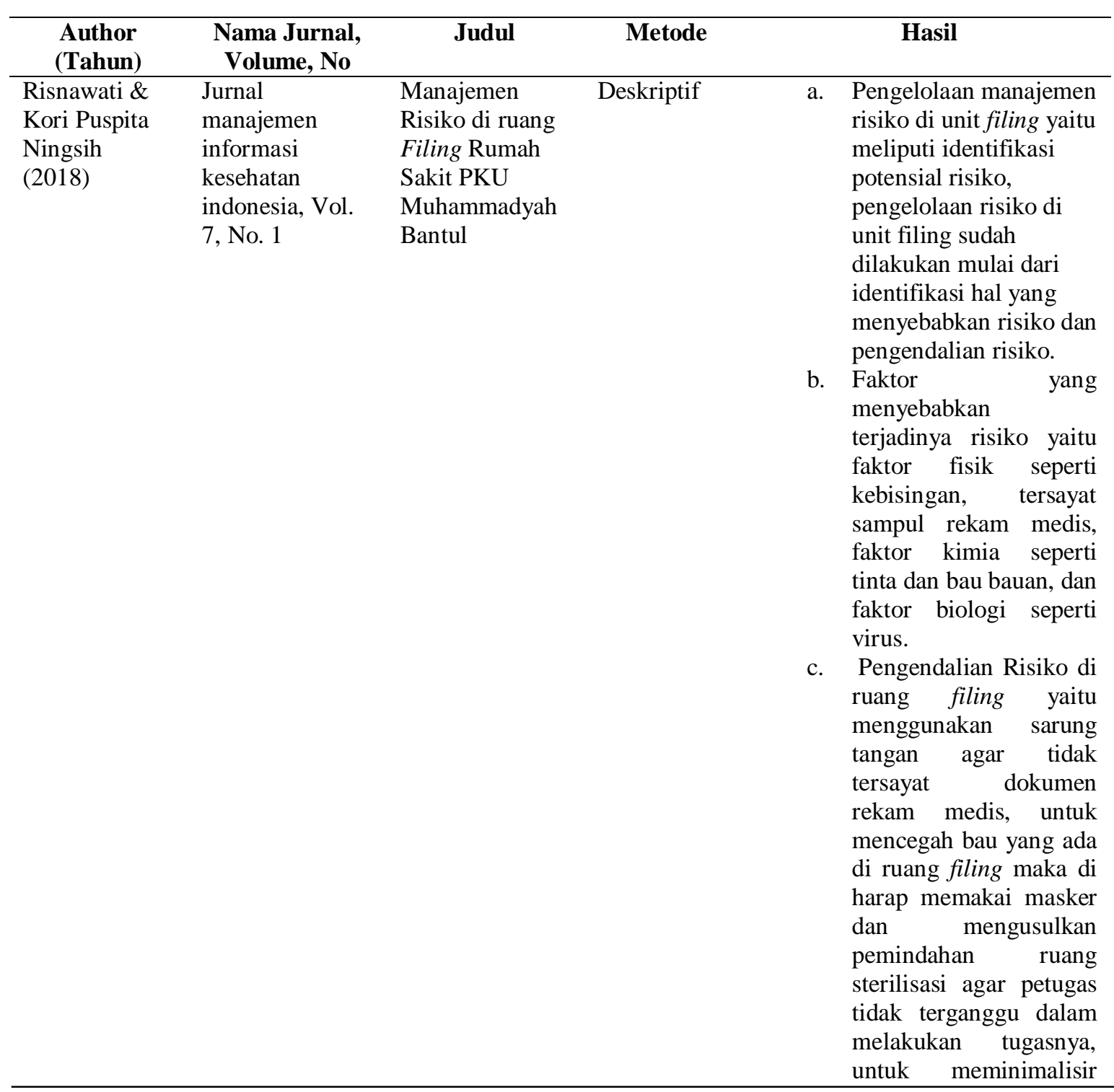




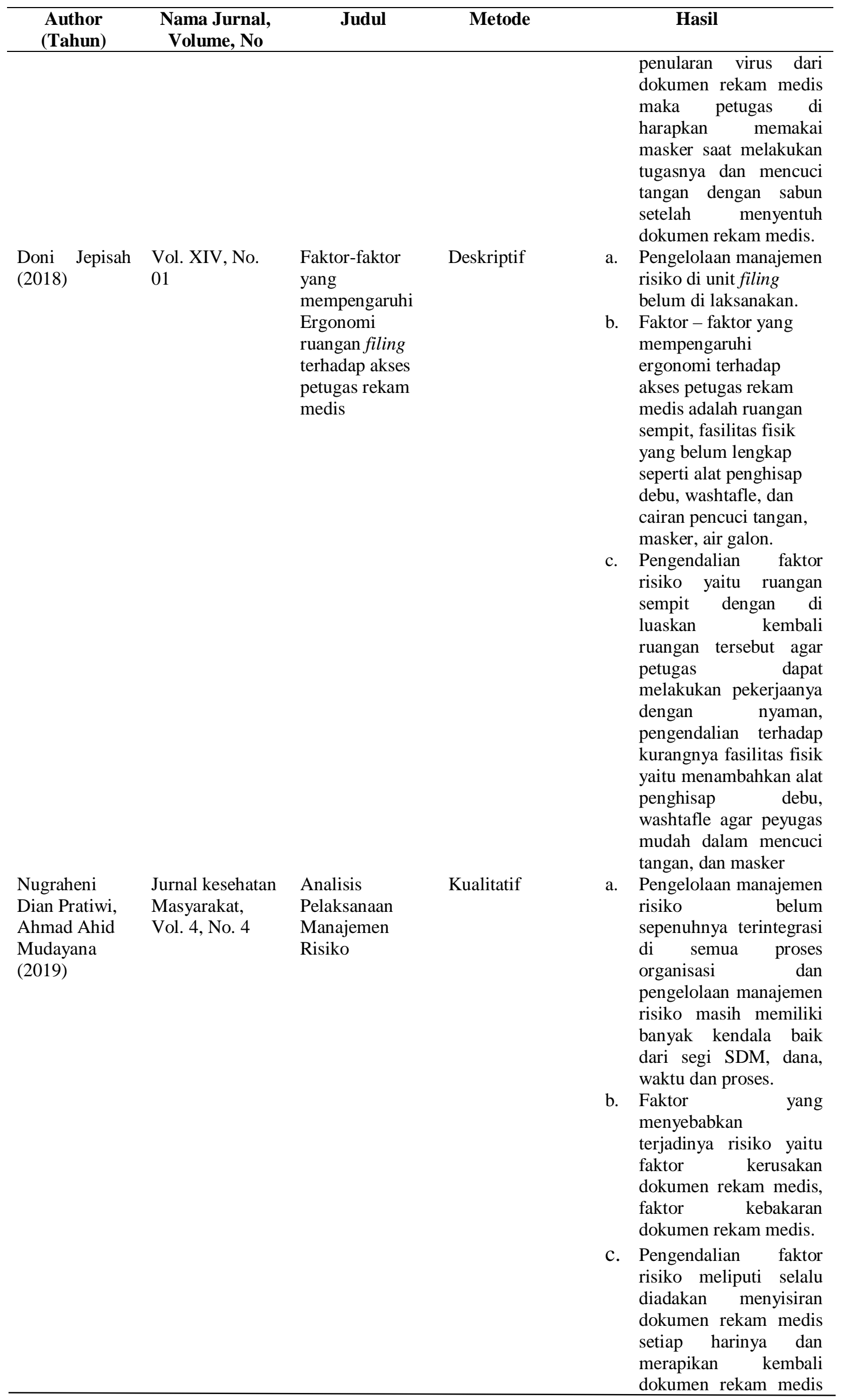




\begin{tabular}{|c|c|c|c|c|c|}
\hline $\begin{array}{l}\text { Author } \\
\text { (Tahun) }\end{array}$ & $\begin{array}{l}\text { Nama Jurnal, } \\
\text { Volume, No }\end{array}$ & Judul & Metode & & Hasil \\
\hline $\begin{array}{l}\text { Inggil De } \\
\text { Crystal, Efri } \\
\text { Tri Ardianti \& } \\
\text { Sustin } \\
\text { Farlinda } \\
(2020)\end{array}$ & $\begin{array}{l}\text { Jurnal Rekam } \\
\text { Medik dan } \\
\text { Informasi } \\
\text { kesehatan, } \\
\text { Vol.1, No.3 }\end{array}$ & $\begin{array}{l}\text { Analisis } \\
\text { Penerapan } \\
\text { Risiko Kerja } \\
\text { Petugas Filing }\end{array}$ & Kualitatif & b. & 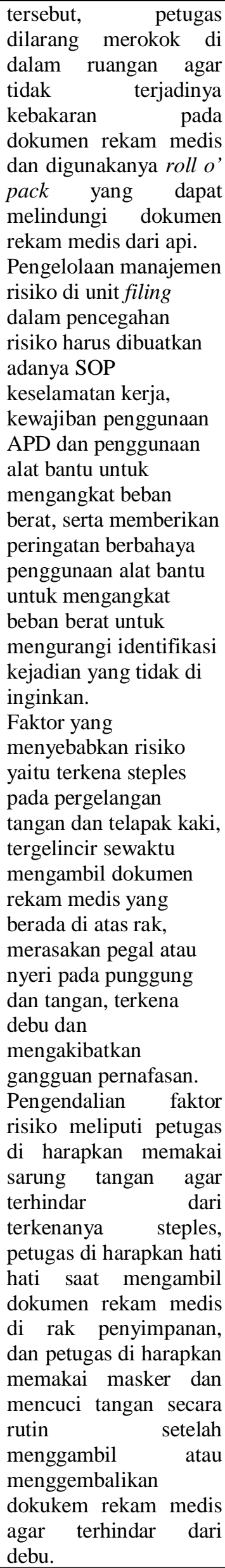 \\
\hline
\end{tabular}




\begin{tabular}{llll}
\hline \multicolumn{1}{c}{$\begin{array}{c}\text { Author } \\
\text { (Tahun) }\end{array}$} & $\begin{array}{c}\text { Nama Jurnal, } \\
\text { Volume, No }\end{array}$ & \multicolumn{1}{c}{ Judul } & Metode \\
\hline Bayu Aji & Jurnal & Tinajuan & Deskriptif \\
Santoso \& Sri & manajemen & Penerapan & \\
Sugiarsi & informasi & Manajemen & \\
$(2017)$ & kesehatan & Risiko di unit & \\
& indonesia, Vol.5, & Filing & \\
& No.2 & &
\end{tabular}

\section{Hasil Sintesis}

Berdasarkan hasil ekstrasi data maka ditemukan hasil sintesis sebagai berikut :
a. Pengelolaan manajemen risiko di unit filing

\section{B. PEMBAHASAN}

1. Pengelolaan manajemen risiko di unit filing

Berdasarkan Risnawati dan Kori Puspita Ningsih (2018) menjelaskan bahwa Pengelolaan manajemen risiko di unit filing yaitu meliputi identifikasi potensial risiko, pengelolaan risiko di unit filing sudah dilakukan mulai dari pengidentifikasian hal yang menyebabkan risiko dan pengendalian risiko. Sedangkan perbedaan pada Rachmawati Yulianingthyas, dkk (2016) Pengelolaan manajemen risiko belum sepenuhnya terintegrasi di semua proses organisasi dan pengelolaan manajemen risiko masih memiliki banyak kendala baik dari segi SDM, dana, waktu dan proses. Menurut Inggil De Crystal, dkk (2020) Pengelolaan manajemen risiko di
Hasil

a. Pengelolaan manajemen risiko di gunakan untuk melakukan identifikasi dan mengurangi kejadian yang tidak diinginkan dan menggurangi risiko terhadap keselamatan petugas, Pengelolaan manajemen risiko dilakukan secara internal.

b. Faktor risiko yaitu faktor fisik seperti kebisingan, dokumen rekam medis rapuh, sesak nafas alergi batuk, faktor kimia seperti tinta, dan faktor biologi seperti serangan rayap dan serangga, virus

c. Pengendalian faktor risiko yaitu kebisingan dengan cara dipasangnya pintu kaca yang dapat meredam gangguan dari luar,memasang AC selama jam bekerja agar tidak terjadinya dokumen rekam medis rapuh, memakai masker dan mencuci tangan setelah mengambil dan menggembalikan dokumen rekam medis agar tidak terserang batuk, sesak nafas dan alergi

b. Faktor yang mempengaruhi terjadinya risiko di unit filing

c. Pengendalian risiko di unit filing

unit filing dalam pencegahan risiko harus dibuatkan adanya SOP keselamatan kerja, kewajiban penggunaan APD dan penggunaan alat bantu untuk mengangkat beban berat, serta memberikan peringatan berbahaya penggunaan alat bantu untuk mengangkat beban berat untuk mengurangi identifikasi kejadian yang tidak di inginkan. Hal ini sudah sesuai dengan teori menurut Nabilatul Fanny dan Anindya Soviani, (2020) menjelaskan bahwa keselamatan pasien merupakan suatu sistem yang membuat asuhan pasien lebih aman, meliputi identifikasi risiko dan pengelolaan risiko pasien, pelaporan dan analisis insiden, serta implementasi solusi untuk meminimalkan timbulnya risiko, meminimalisir angka kejadian yang tidak diinginkan dan mencegah terjadinya cidera yang disebabkan oleh kesalahan akibat melaksanakan suatu tindakan. 
Berdasarkan penelitian tersebut dapat di simpulkan bahwa pengelolaan manajemen risiko di unit filing sepenuhnya sudah terlaksanakan mulai dari identifikasi yang menyebabkan risiko, dalam pencegahan risiko perlu dibuatkanya SOP dalam keselamatan bekerja untuk meminimalisir angka kejadian yang tidak di inginkan dan mencegah terjadinya cidera yang disebabkan akibat kesalahan dalam melaksanakan suatu tindakan.

\section{Faktor risiko kerja petugas filing di unit filing}

Menurut Bayu Aji Santoso \& Sri Sugiarsi, (2017) dan Risnawati \& Kori Puspita Ningsih, (2018) terdapat kesamaan yang menjelaskan bahwa langkah pertama manajemen risiko adalah mengidentifikasi risiko apa saja yang dapat mempengaruhi pencapaian sasaran organisasi, pada tahap ini dilakukan identifikasi faktor risiko kesehatan yang dapat tergolong fisik, kimia, biologi, dan faktor kerusakan DRM. Hal ini sesuai dengan Permenkes No 25 Tahun 2019 yang menyatakan risiko suatu peristiwa yang berdampak negative terhadap pencapaian sasaran organisasi. Sedangkan perbedaan faktor penyebab risiko menurut Doni Jepisah, (2018) yaitu masih terdapat faktor - faktor yang mempengaruhi ergonomi terhadap akses petugas rekam medis adalah ruangan sempit, fasilitas fisik yang belum lengkap,. Menurut Risnawati, dkk (2018) dan Inggil De Crystal, dkk (2020) terdapat kesamaan yaitu faktor penyebab terjadinya risiko adalah tersayat sampul rekam medis, terkena steples di pergelangan tangan dan telapak kaki, tertimpa rak atau berkas yang jatuh, tergelincir sewaktu menggambil berkas rekam medis yang berada diatas rak, merasakan pegal atau nyeri pinggang, punggung dan tangan, dan terkena debu yang dapat mengakibatkan gangguan pernafasan. Berdasarkan penelitian diatas dapat disimpulkan bahwa faktor risiko di unit filing yang paling menonjol adalah faktor fisik seperti kebisingan, faktor kimia seperti bau bauan dan faktor biologi seperti seranggan rayap.

3. Pengendalian faktor risiko yang terjadi pada petugas kerja filing di ruang filing

a. Faktor fisik

1) Kebisingan

Kebisingan yang bersumber dari alat sterill dan suara lift, suara kebisingan tersebut sangat menganggu kenyamanan petugas di ruang filing dalam melakukan tugasnya (Risnawati dan Kori Puspita Ningsih, 2018). Sedangkan perbedaan menurut penelitian Bayu Aji Santoso dan Sri Sugiarsi, (2017) faktor kebisingan yang bersumber dari proyek yang sedang berlangsung , dari suara kegiatan tersebut maka dapat menganggu tingkat konsentrasi dan kenyamanan petugas rekam medis dalam menjalankan tugasnya.

Cara pengendalian untuk menggurangi suara bising atau gangguan dari luar di unit filing adalah dengan dipasangnya pintu kaca yang dapat meredam gangguan suara dari luar (Bayu Aji Santoso dan Sri Sugiarsi, 2017). Sedangkan cara pengendalian faktor kebisingan menurut Risnawati dan Kori Puspita Ningsih, (2018) yaitu dengan adanya pengajuan pemindahan ruang sterilisasi dan juga pengajuan untuk penggantian lift baru agar tidak menganggu petugas filing dalam melaksanakan tugasnya.

2) Dokumen rekam medis rapuh

Dokumen rekam medis rapuh dapat disebapkan karena cahaya dan suhu, contohnya adalah dokumen rekam medis dapat mudah rusak jika kondisi suhu dan pencahayaan tidak dijaga dengan baik, cara pengendalianya yaitu dengan memasang AC dari waktu kerja petugas filing sampai selesai (Bayu aji Santoso dan Sri Sugiarsi, 2017).

3) Tersayat sampul rekam medis

Tersayat sampul rekam medis termasuk faktor fisik contohnya dokumen dapat mudah rusak, untuk sampul berkas rekam medis masih menggunakan sampul dengan bahan glossy dan juga terdapat formulir di dalam berkas rekam medis yang di steples akan terjadi luka jika petugas tidak berhati-hati maka kemungkinan besar petugas dapat tersayat sampul rekam medis sat menggambil berkas di rak penyimpanan. Cara pengendalianya yaitu petugas menggunakan sarung tangan agar terlindung dari tesayat dokumen rekam medis dan mengganti sampul berkas rekam medis dengan yang sudah terstandar yaitu sampul yang tidak glossy ( Bayu Aji Santoso dan Sri Sugiarsi, 2017).

4) Sesak nafas, alergi dan batuk

Sesak nafas, alergi dan batuk merupakan termasuk dalam faktor fisik yang di sebabkan oleh debu tersebut berasal dari rak rekam medis maupun dokumen rekam medis pasien yang berdebu sehingga menyebabkan batuk batuk, sesak nafas, bahkan alergi pada kulit (Bayu Aji Santoso dan Sri Sugiarsi, 2017).

Cara pengendalian menurut Bayu Aji Santoso dan Sri Sugiarsi, (2017) yaitu bagi seluruh petugas filing harus menggunakan masker saat bekerja dan mencuci tangan setelah menyentuh dokumen rekam medis pasien, serta dibersihkanya rak rekam medis secara 
rutin setiap hari menggunakan penyedot debu.

b. Faktor kimia

1) Bau - bauan

Menurut Bayu Aji Santoso \& Sri

Sugiarsi (2017) dan Risnawati \& Kori Puspita Ningsih (2018) terdapat kesamaan yaitu bau tersebut di sebabkan bau kertas berkas rekam medis yang telah lama di simpan di rak sehingga dapat menyebabkan pusing pada petugas unit filing. Cara pengendalianya untuk menghilangkan bau-bau yang berada di uni filing yang bersumber dari dokumen rekam medis yang telah tersimpan lama adalah dengan memasang AC.

c. Faktor biologi

1) Serangan rayap dan serangga

Menurut Bayu Aji Santoso dan Sri Sugiarsi, (2017) Rayap dan serangga meupakan musuh utama bagi petugas rekam medis terutama bagian unit filing, rayap atau serangga lainya biasanya menyerang pada dokumen rekam medis. Cara pengendalianya untuk mencegah timbulnya atau munculnya rayap atau serangga di unit filing meliputi rak rekam medis yang terbuat dari besi dan ruangan sering di semprot dengan racun serangga untuk mencegah munculnya serangga yang merusak dokumen rekam medis.

2) Virus

Pada Bayu Aji Santoso dan Sri Sugiarsi, (2017) Virus yang bersumber dari dokumen rekam medis pasien apabila tidak menggunakan masker dan cuci tangan setelah menyentuh dokumen rekam medis pasien, akibatnya adalah virus akan mudah menular ketubuh petugas unit lain. Sedangkan perbedaan menurut penelitian Risnawati dan Kori Puspita Ningsih, (2018) virus yang bersumber dari dokumen rekam medis yang dikembalikan dari poli setelah pelayanan selesai jika petugas tidak menggunakan masker dan anti septik akibatnya adalah virus akan mudah masuk ke hidung dan mulut petugas. Perbedaan cara pengendalian pada Bayu Aji Santoso \& Sri Sugiarsi, (2017) dan Risnawati \& Kori Puspita Ningsih, (2018), cara pengendalian untuk meminimalisir penularan virus dari dokumen rekam medis pasien ke tubuh petugas filing adalah adanya perintah untuk menggunakan masker pada saat bekerja dan mencuci tangan dengan sabun setelah menyentuh dokumen rekam medis dan adanya anjuran untuk semua pegawai agar rajin mengecek kesehatan (Bayu Aji Santoso dan Sri Sugiarsi, 2017). Cara pengendalianya untuk meminimalisir penularan virus adalah adanya perintah untuk menggunakan masker pada saat bekerja dan mencuci tangan dengan sabun setelah menyentuh dokumen rekam medis penggunaan APD (Risnawati dan Kori Puspita Ningsih, 2018) .

d. Faktor ergonomi

Persamaan faktor ergonomic Bayu Aji Santoso. (2017) dan Risnawati dan Kori Puspita Ningsih, (2018) Penyebab faktor ergonomi diantaranya adalah risiko jatuh, nyeri pinggang, dan nyeri bahu. Hal tersebut dikarenakan ruang filing menggunakan tipe rak rekam medis yang terbuka yang terbuat dari besi yang tingginya tidak sesuai standar ukuran rak penyimpanan, sehingga dokumen rekam medis penuh di rak penyimpanan. Perbedaan cara pengendalian Bayu Aji Santoso dan Sri Sugiarsi, (2017) faktor ergonomic merupakan faktor risiko yang paling kelihatan di unit filing, untuk menangani masalah tersebut harus menyediakan rak rekam medis tidak terlalu tinggi, dan menambah beberapa petugas di unit filing yang berposter tubuh tinggi dan berusia muda guna untuk meningkatkan efektifitas dalam pelayanan. Sedangkan pada Risnawati dan Kori Puspita Ningsih, (2018) untuk meminimalisir rak filing yang tidak memadai dengan cara menyimpan berkas rekam medis di dalam kardus dan diletakkan di lorong rak berkas rekam medis.

\section{SIMPULAN}

1. Pengelolaan manajemen risiko di unit filing sepenuhnya sudah terlaksanakan mulai dari identifikasi yang menyebabkan risiko, dalam pencegahan risiko perlu dibuatkanya SOP dalam keselamatan bekerja untuk meminimalisir angka kejadian yang tidak di inginkan dan mencegah terjadinya cidera yang disebabkan akibat kesalahan dalam melaksanakan suatu tindakan.

2. Faktor risiko yang mempengaruhi petugas kerja di unit filing yaitu meliputi faktor kimia termasuk bau bauan, faktor biologi seperti serangan rayap dan serangga serta virus, faktor fisik seperti kebisingan, dokumen rekam medis rapuh, tersayat dokumen rekam medis dan sesak nafas alergi dan batuk

3. Pengendalian risiko petugas filing di unit filing yaitu faktor fisik seperti kebisingan dilakukan pengendalian dengan cara dipasangnya pintu kaca yang dapat meredam gangguan suara dari luar, faktor kimia seperti bau bauan dilakukan pengendalian dengan cara di pasangnya $\mathrm{AC}$ di dalam ruangan dan faktor biologi seperti serangan rayap dan serangga dilakukan pengendalian dengan cara ruangan sering di semprot dengan racun serangga untuk mencegah munculnya serangga yang merusak dokumen rekam medis. 


\section{DAFTAR PUSTAKA}

Crystal, I. De, Ardianto, E. T., Farlinda, S., Kesehatan, J., Jember, P. N., Assessment, S., Filling, P., \& Inap, R. (2020). J-REMI : Jurnal Rekam Medik Dan Informasi Kesehatan Analisis Risiko Kerja Petugas Filling Rawat Inap Dengan Menggunakan Severity Assessment Di Rsup Dr. Hasan Sadikin Bandung J-REMI : Jurnal Rekam Medik Dan Informasi Kesehatan. 1(3), 113-119.

Fanny, N., \& Soviani, A. (2020). Analisis Manajemen Risiko Di Ruang Filing RSUD dr Soediran Mangun Sumarso Wonogiri Tahun 2020. 10(2), 12-19.

Jepisah, D. (2020). Faktor-Faktor Yang Mempengaruhi Ergonomi Ruangan Filling Terhadap Akses Petugas Rekam Medis Di Rsud Siak Tahun 2018 Faktors That Influence The Ergonomy Of The Filling Room On The Access To Medical Recording Officers In Siak Hospital, 2018. XIV(01), 43-49.

Kresnowati, L., Susanto, E., \& Nurfalah, T. I. (2019). Kesehatan dan Keselamatan Kerja ( K3 ) di Bagian filing. 34-38.

Medika, P., Bali, H., \& Nasional, U. P. (2019). Strategi Investasi \& Manajemen Resiko Rumah Sakit Swasta di Bali by Ni Ketut Yunita Wulan Dewi (1) Gede Sri Darma (2). 16(2), 110-127.

Ningsih, K. P., Tunnisa, U., \& Erviana, N. (2020). Manajemen Resiko Redesign Sistem Penjajaran
Rekam Medis dengan Metode Failure Mode and Effect Analysis ( FMEA ). 8(1), 8-20.

Nugraheni, S. W., Firdaus, E. N., \& Agustine, V. D. (2019). Risk Management In Hospital Filing Unit. 1, 59-62.

Prof, J., Ildrem, M., Tahun, M., \& Kunci, K. (2019). Tinjauan Pelaksanaan Pemeliharaan Dokumen Rekam Medis Di Ruang Filing Rumah Sakit. 1, 560-566.

Santoso, B. A., \& Sugiarsi, S. (2011). Tinjauan Penerapan Manajemen Risiko Di Unit Filing RSUD Dr. MOEWARDI. 19-26.

Susilo, J., Studi, P., Medis, R., Informasi, D., Fakultas, K., Universitas, K., \& Semarang, D. N. (2019). VISIKES : Jurnal Kesehatan Masyarakat. 146154.

Talib, T. (2018). Analisis Beban Kerja Tenaga Filing Rekam Medis (Studi Kasus Rumah Sakit Ibu Dan Anak Bahagia Makassar). Jurnal Manajemen Informasi Kesehatan Indonesia, 6(2), 123. https://doi.org/10.33560/.v6i2.196

Yulianingtyas, R., Wigati, P., \& Suparwati, A. (2016). Analisis Pelaksanaan Manajemen Risiko Di Rumah Sakit Islam Sultan Agung Semarang. Jurnal Kesehatan Masyarakat (e-Journal), 4(4), 121-128. 